Adapun mesin pencacah (penghancur) yang umum digunakan sebagai penghancur bahan padat dapat dibedakan menurut jenis bahan yang akan dihancurkan, misalnya untuk bahan yang keras, dengan kekerasan 4 skala Mohs keatas, digunakan mesin pencacah jenis Jaw Crushers, Gyratory Crushers dan Disk Crushers, sedangkan untuk bahan yang lebih lunak dengan kekerasan antara 3 sampai 4 skala Mohs, seperti batu bara, gypsun, batu kapur, es, clay dan batu tulis, digunakan mesin pencacah jenis Hammer mill dan Toothed roll. wocthet.

Sedangkan mesin pencacah untuk proses ulang bahan dari jenis thermoplastik seperti Poly Etilen, Poly Styren, Poly Vinil Chlorida, Sellullosa dan jenis thermoplastik lain, adalah mesin pencacah limbah plastik dengan motor penggerak listrik yang bertenaga antara 5 sampai $50 \mathrm{Hp}$. Pada mesin pencacah ini dilengkapi dengan alat pemotong yang berbentuk pisau sebanyak 7 buah, yaitu 4 buah pisau tetap (stasioner) dan 3 buah pisau yang berputar. Mesin pencacah ini dilengkapi juga dengan ayakan yang bisa diganti menurut keperluan, dengan diameter lubang ayakan antara $1 / 8$ in sampai 3/8 in dan kapasitas mesin antara 100 sampai $1000 \mathrm{lb} / \mathrm{jam}$.

Mesin pencacah limbah plastik merupakan mesin untuk menghancurkan barang-barang plastik jenis thermoplastik menjadi bagian yang lebih kecil. Rancang bangun mesin pencacah dapat dioperasikan secara basah maupun kering. Sedangkan manfaat dari sistim basah adalah penggunaan pisau ang lebih tahan lama, sebab panas yang ditimbulkan relatif rendah. Disamping itu kotoran dari bahan plastik yang dihancurkan langsung keluar bersih, ehingga saluran penyaring tidak tersumbat dalam hal ini akan lebih mempantu kelancaran petugas dalam mengoperasikan mesin. Adapun kelemahan lari sistim basah, bahwa pisau pencacah setiap saat harus dikontrol dan bila kelihatan tumpul perlu digerinda posisi yang diinginkan.

\title{
PENDAHULUAN
}

Akhir-akhir ini limbah plastik, seperti : ember, pipa plastik, serpihan akalan acuan, bakalan acuan sepatu dan lain-lain, makin menumpuk dan ila dibiarkan akan menimbulkan dampak negatif terhadap lingkungan hilup. Mengingat sifat plastik yang sulit membusuk, maka untuk menangzulangi sampah plastik tersebut dilakukan suatu daur ulang yaitu dengan ara dicacah dan kemudian dibuat pellet, sehingga dapat diolah kembali nenjadi produk lain.

Untuk mencacah limbah plastik dari jenis thermoplastik perlu dibuat perekayasaan mesin pencacah limbah, karena di Indonesia saat ini masih sedikit abrik yang menagani pengolahan limbah plastik.

Tujuan dari rancang bangun ini adalah membuat suatu rancangan mesin ang dapat digunakan untuk memanfaatkan plastik dari jenis thermoplastik nenjadi bahan baku reklaim.

Mesin pencacah adalah mesin yang digunakan untuk menghancurkan ahan yang besar menjadi bahan yang lebih kecil. 


$$
\begin{aligned}
\text { Putaran }=N_{I I} & =\frac{D_{I}}{D_{I I}} \times N_{I} \\
& =\frac{12,5}{25} \times 1465 \mathrm{rpm} \\
& =732,5 \mathrm{rpm}
\end{aligned}
$$

Secara teoritis : Putaran pisau $=$ Putaran pulley atas $=732,5 \mathrm{rpm}$. Dari tabel kapasitas mesin Jenis Gyratory Crushers, untuk putaran pulley $=700 \mathrm{rpm}$ $\longrightarrow$ Kapasitas cacahan $=700 \mathrm{lb} / \mathrm{jam}$

$$
=317,52 \mathrm{~kg} / \mathrm{jam} \text {. }
$$

Maka untuk putaran pulley $=732,5 \mathrm{rpm}$, secara teoritis : Kapasitas cacahan $=\frac{732,5}{700} \times 317,52 \mathrm{~kg} / \mathrm{jam}=332,262 \mathrm{~kg} / \mathrm{jam}$.

Jadi dalam rancang bangun ini kapasitasnya diperkirakan sekitar $325 \mathrm{~kg} / \mathrm{jam}$.

\section{IIASIL RANCANG BANGUN MESIN PENCACAH LIMBAH PLASTIK}

Hasil rancang bangun mesin pencacah limbah plastik mempunyai spesifikasi teknis sebagai berikut :

1. Baja as: Panjang $(\mathrm{L})=65 \mathrm{~cm}$

Diameter $(\varnothing)=7,5 \mathrm{~cm}$

2. Lager kogel : Diameter lingkaran dalam $(\varnothing)=7,0 \mathrm{~cm}$

3. Motor: Motor induksi

$15 \mathrm{PK}, 380$ Volt, $1465 \mathrm{rpm}$.

Pisau : - 4 batang pisau yang berputar, dengan ukuran masing-masing $(25 \times 7 \times 2) \mathrm{cm}$.

2 batang pisau stasioner, dengan ukuran masing-masing $(25 \mathrm{x}$ $7 \times 2) \mathrm{cm}$.

$V$ - belt : Jenis B, sebanyak 4 ban.

6. Pulley : Atas $\longrightarrow$ Diameter $(\varnothing)=25 \mathrm{~cm}$

$$
\text { Tebal }=7,5 \mathrm{~cm}
$$

Bawah $\longrightarrow$ Diameter $(\varnothing)=12,5 \mathrm{~cm}$

$$
\text { Tebal }=7,5 \mathrm{~cm}
$$

7. Balancing : Diameter $(\varnothing)=40 \mathrm{~cm}$

$$
\text { Tebal } \quad=4 \mathrm{~cm}
$$

8. Penyaring: Plat baja, $\varnothing$ lubang $=1,5 \mathrm{~cm}$, jarak lubang $0,5 \mathrm{~cm}, T$ Tebal $=1 \mathrm{~cm}$.

9. Kapasitas : $325 \mathrm{~kg} / \mathrm{jam}$.

10. Dilengkapi dengan pipa air dengan ukuran diameter $(\varnothing)=1,5$ in dan 1 buah sprayer air.
Sedangkan cara kerja mesin pencacah limbah plastik hasil rancang bangun adalah:

1. Cek voltase motor dan sumber arus.

2. Hidupkan mesin.

3. Jalankan pisau pencacah dengan menekan tombol "ON".

4. Masukkan barang-barang plastik bekas yang sejenis sebagai bahan bakunya, sedang untuk bahan yang besar perlu dilakukan pencacahan pendahuluan.

5. Bila bahan bakunya bersih kran air tidak perlu dibuka, sehingga bahan bakunya langsung masuk ke pisau pencacah, tetapi bila bahan bakunya kotor maka kran air dibuka, sehingga membasahi bahan baku yang akan masuk ke pisau pencacah.

6. Hasil cacahan plastik bekas keluar lewat penyaring, sedang yang belum bisa keluar dari penyaring terangkat kembali karena putaran pisau.

7. Hasil yang keluar dari mesin untuk bahan yang bersih langsung ditampung oleh karung sedang untuk bahan yang masih kotor, hasil cacahannya masih basah, sehingga diperlukan proses pencucian didalam bak pencuci, kemudian ke proses pengering yang menggunakan udara panas. 


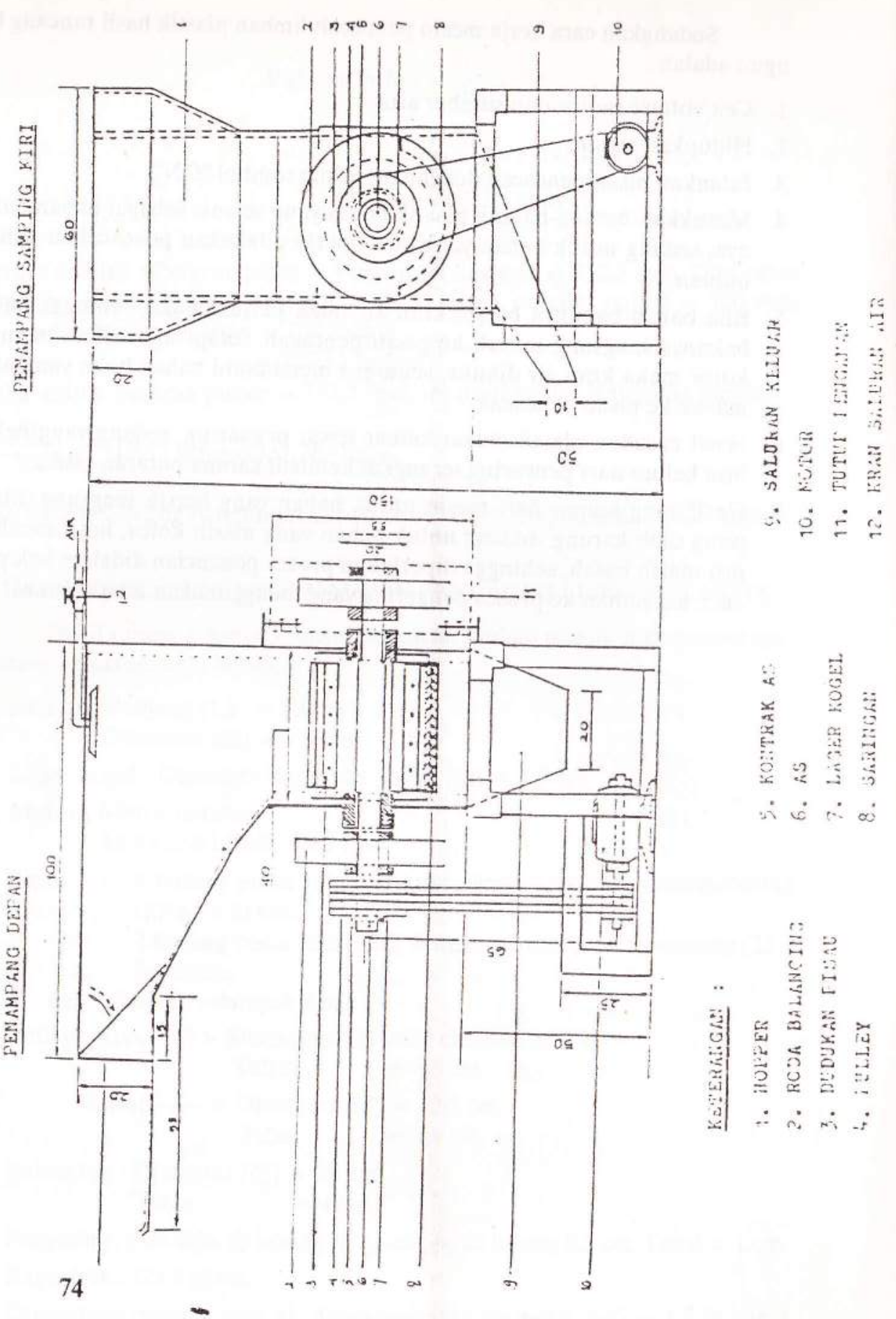

Dari hasil rancang bangun mesin pencacah limbah plastik dap diambil kesimpulan bahwa prosesnya bisa menggunakan cara basah dan ca kering.

Dimana penggunaan cara basah ini mempunyai keuntungan antara lair pemakaian pisau yang lebih awet karena panas yang ditimbulkan rela kecil, bahan baku langsung tercuci dari kotoran yang melekat, maka de tidak beterbangan, sehingga tidak mengganggu para pekerja.

Sedangkan kelemahan dari mesin ini adalah pisau yang berputar maup pisau stasioner harus sering dikontrol dan bila sudah kelihatan tumpul per digerinda.

\section{KEPUSTAKAAN}

1. Dinamika Perdana Sakti Machinery Trade and Enggineering, PT., Bors Mesin-mesin, Jakarta.

2. George Granger Brown, "Unit Operation", third edition, Tokyo, 197 page $27-32$.

3. Herbert R. Simonds, "Encyclopedia of Plastic Equipment", New Yor 1964. 
- Sulfida : Ada penurunan sulfida yang berkisar antara 49 - $73 \%$ atau $0,04-1,29 \mathrm{mg} /$. Penurunan sulfida tertinggi pada perlakuan limbah samak krom $20 \mathrm{ml} / \mathrm{d}$ dan terendah pada perlakuan dengan limbah $0 \mathrm{~mL} / \mathrm{l}$.

- Krom : Kandungan krom juga mengalami penurunan yang berkisar antara $0,14-0,24 \mathrm{mg} / \mathrm{l}$ atau sebesar $31-83 \%$. Penurunan tertinggi pada perlakuan dengan limbah samak krom $55 \mathrm{ml} / \mathrm{l}$ dan terendah dengan limbah $20 \mathrm{ml} / 1$.

b. Larutan tanpa eceng gondok

Bahan pencemar dalam larutan tanpa eceng gondok pada hari kedua setelah perlakuan ini juga mengalami penurunan walau kecil. Penurunan bahan pancemar tersebut secara rinci adalah sebagai berikut :

- COD : Mengalami penurunan yang berkisar antara $0,56-21,68 \mathrm{mg} / \mathrm{l}$ atau $0,5-14 \%$. Penurunan tertinggi pada perlakuan dengan limbah krom $20 \mathrm{ml} / \mathrm{l}$ dan terendah pada perlakuan dengan $15 \mathrm{ml}$ air limbah/l air sumur.

- BOD : Penurunan BOD hanya terjadi pada perlakuan dengan air limbah $10 \mathrm{ml} / \mathrm{l}$ sebesar $2 \mathrm{mg} / \mathrm{latau}$ $7 \%$.. Perlakuan yang lain dengan air llimbah 0 , 5,15 dan $20 \mathrm{ml} / \mathrm{j}$ justru ada kenaikan, masingmasing sebesar: $31 \%, 12 \%, 112 \%$ dan $73 \%$.

- Klorida : Ada penurunan klorida antara 0,9-9\% atau sebesar $1,93-49,69 \mathrm{mg} /$.

- Sulfida : Ada penurunan sulfida yang cukup besar antara $2-24 \%$ atau sebesar $0,02-0,29 \mathrm{mg} / \mathrm{l}$. Penurunan tertinggi pada perlakuan dengan limbał samak krom $15 \mathrm{ml}$, das terendah pada perlakuan dengan limbah samak krom5 dan 10 $\mathrm{ml} / \mathrm{l}$.

Dari hasil percoban a dan b di atas secara umum dapat diketahui bahwa dengan atau tanpa eceng gondok nampak ada penurunan bahan pencemar. Namun demikian penurunan bahan pencemar dengan eceng gondok nampak jauh lebih besar dibanding yang tanpa eceng gondok. Hal ini berarti eceng gondok mampu menurunkan bahan pencemar. Dan apabila dikaitkan dengan pengamatan terhadap kondisi tanaman, maka ada kecenderungan semakin tinggi dosis air limbah krom yang ditambahkan, semakin besar penurunan bahan pencemar, akan tetapi hal ini berarti pula semakin cepat eceng gondok layu dan mati. Adanya kenaikan nilai COD dan BOD diduga 
plastik, yang mana sebelumnya wadah yang digunakan untuk pembibitan tanaman masih menggunakan keranjang bambu. Kantong plastik semakin banyak digunakan karena sifat tahan lama, harganya relatif murah, supply bahan dapat kontinue dan praktis dalam pengangkutannya. Menurut sumber dari Departemen Pertanian dan Departemen Kehutanan kebutuhan kantong plastik untuk pembibitan selama Pelita IV mencapai jumlah 1,71 milyar buah, sedangkan pada Pelita V direncanakan kebutuhan kantong plastik untuk pembibitan mencapai 12,71 milyar buah, atau mengalami peningkatan lebih dari tujuh kali lipat dibanding dengan kebutuhan selama Pelita IV. Berdasarkan data tersebut nampak bahwa penggunaan kantong plastik untuk pembibitan tanaman menunjukkan prospek cerah.

\section{TINJAUAN PUSTAKA}

Usaha budi daya tanaman kini semakin berkembang dengan pesat baik itu untuk tanaman pertanian, perkebunan maupun kehutanan. Salah satu usaha agar diperoleh produk tanaman yang berkualitas baik adalah melakukan pembibitan dengan menggunakan wadah kantong plastik. Hal ini dikarenakan pada waktu bibit tanaman akan dipindah ke lapangan, bibit tidak mengalami kerusakan akar sehingga tidak terjadi istirahat tumbuh. Kemudian pada waktu pemeliharaan, penggunaan pupuk yang akan lebih efektif sehingga dapat menghasilkan bibit yang kuat dan dapat menekan angka kematian tanaman.

Kantong plastik yang dapat digunakan untuk wadah pembibitan tanaman ada dua macam, yaitu kantong plastik yang tidak berwarna (transparan) yang bisa terbuat dari bahan polietilen. Kantong plastik yang paling sesuai untuk pembibitan tanaman adalah yang berwarna hitam, kantong plastik yang berwarna transparan kurang menguntungkan karena dapat mempercepat tumbuhnya cendawan atau jamur pada akar tanaman dan kurang menyerap panas sinar matahari, sehingga dapat memperbesar angka kematian bibit yang ditanaman.

\section{MATERI DAN METODE PENELITIAN}

\section{MATERI}

Materi yang digunakan dalam penelitian ini adalah data sekunder yang diperoleh dari survei perusahaan kantong plastik, distributor mesin dan studi pustaka yang berkaitan dengan rancang bangun pabrik kantong plastik untuk pembibitan. Kapasitas produksi yang direncanakan sebesar $276480 \mathrm{~kg}$ per tahun atau $960 \mathrm{~kg}$ per hari. 


\section{METODE PENELITIAN}

Data yang diperoleh dari hasil penelitian diolah dengan menggunakan metode Peter dan Timmer Haus, 1978 sehingga dapat diketahui

- Prosentase nilai batas rugi laba

- Kapasitas pengembalian modal (rate of return)

- Waktu minimal untuk pengembalian modal

\section{HASIL DAN PEMBAHASAN}

Kegunaan dan pemasaran

Kegunaan : untuk wadah pembibitan tanaman

Pemasaran : Kebutuhan dalam negeri

8. Spesifikasi produk

Nama : kantong plastik untuk pembibitan (polybag)

Bahan : polietilen

Tebal : $0,03-0,2 \mathrm{~mm}$

Warna : Hitam

C. Diagram Alir Kualitatip

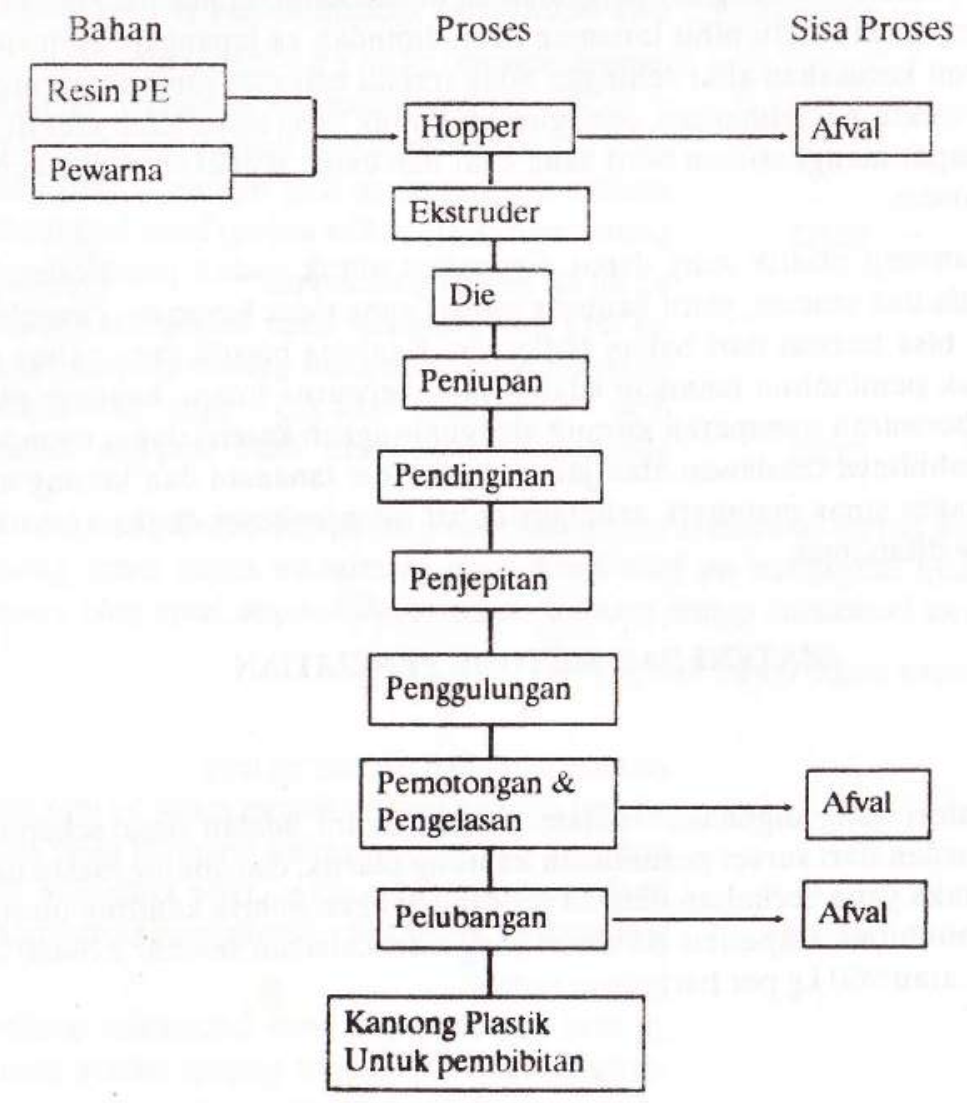

\section{PERHITUNGAN EKONOMI}

Hasil perhitungan ekonomi ini akan memberikan gambaran berapa besarnya modal yang dibutuhkan untuk mendirikan pabrik kantong plastik untuk pembibitan dan untuk menentukan harga pokok produksi, maka harus ditentukan dahulu perhitungan modal tetap dan total biaya produksinya.

1. Perhitungan Modal

1.1. Modal Tetap
a. Harga alat
b. Pemasangan alat, $10 \%$ (a)
c. Service fasilitas \& yard imp. $10 \%$ (a)
d. Instalasi listrik, $10 \%$ (a)
e. Tanah dan bangunan
f. Total biaya langsung
g. Engineering \& supervision, $15 \%$ (f)
h. Ongkos pemborong, $10 \%$ (f)
i. Total biaya langsung \& tak langsung
j. Biaya tak terduga, $10 \%$ (i) Jumlah modal tetap

1.2. Modal Kerja
a. Bahan baku 3 bulan
b. Listrik 3 bulan
c. Gaji pegwai 3 bulan
d. Pengemasan 3 bulan

Jumlah modal kerja

$$
\begin{aligned}
& =\text { Rp. } \quad 92.380 .000,00 \\
& =\text { Rp. } \quad 9.238 .000,00 \\
& =\text { Rp. } \quad 9.238 .000,00 \\
& =\text { Rp. } \quad 9.238 .000,00 \\
& =\text { Rp. } 141 \cdot 600.000,00 \\
& =\text { Rp. } 261 \cdot 694 \cdot 000,00 \\
& =\text { Rp. } \quad 39.254 .100,00 \\
& =\text { Rp. } \quad 26.169 .400,00 \\
& =\text { Rp. } 327 \cdot 117 \cdot 500,00 \\
& =\text { Rp. } 32.711 \cdot 750,00 \\
& =\text { Rp. } 359.829 .250,00
\end{aligned}
$$

$=$ Rp. $228.600 .000,00$

$=$ Rp. $\quad 3.746 .284,00$

$=$ Rp. $\quad 15.705 .000,00$

$=$ Rp. $\quad 1.728 .000,00$

$=$ Rp. $249.779 .284,00$

Total modal $=$ modal tetap $r$ mosial kerja

$$
\begin{aligned}
& =\text { Rp. } 359.829 .250,00+\text { Rp. } 249.779 .284,00 \\
& =\text { Rp. } 609 \cdot 608 \cdot 534,00
\end{aligned}
$$

2. Perhitungan total biaya produksi

2.1. Biaya tidak tetap 1 tahun
a. Bahan baku 1 tahun
b. Pengemasan 1 tahun
c. Listrik 1 tahun

Jumlah biaya tidak tetap

$=$ Rp. $721.520 .000,00$

$=$ Rp. $\quad 5.529 .600,00$

=Rp. $\quad 14.985 .139,00$

$=$ Rp. $742.034 .739,00$ 
2.2. Biaya tetap 1 tahun
a. Gaji 1 tahun
$=$ Rp. $\quad 62.820 .000,00$
b. Pemeliharaan, $2 \%$ (modal tetap)
$=$ Rp. $\quad 7.196 .585,00$
c. Bunga modal : $15 \%$ modal tetap
$18 \%$ modal kerja
$=$ Rp. $53,974.387,00$
=Rp. $44.960 .271,00$
$=$ Rp. $28.786 .340,00$
= Rp. $\quad 6.282 .000,00+$
$=$ Rp. 204.019.583,00
e. Biaya umum, $10 \%$ (gaji 1 tahun) Jumlah biaya tetap

= biaya tidak tetap + biaya tetap

$=$ Rp. $742.034 .739,00+$ Rp. $204.019 .583,00$

$=$ Rp. $946.054 .322,00$

Perhitungan harga pokok

$$
\text { total biaya produksi } 1 \text { tahun }
$$

Harga Pokok $=$

$$
\begin{aligned}
& \text { jumlah produksi per tahun } \\
& \text { Rp. } 946.054 .322,00
\end{aligned}
$$$$
276.480
$$

$$
=\mathrm{Rp} \cdot 3 \cdot 425,00 / \mathrm{Kg}
$$

4. Perhitungan Keuntungan

a. Hasil penjualan 1 tahun :
276.480 X Rp. $4.000,00$
$=$ Rp. $1 \cdot 105 \cdot 920.000,00$
Afval 1 tahun :
13.824 X Rp. 750,00
$=$ Rp. $\quad 10.368 .000,00$
Rp. $1.116 .288 .000,00$
b. Total biaya produksi
=Rp. $946.054 .322,00$
c. Keuntungan sebelum pajak
$=$ Rp. $\quad 170.233 .678,00$
d. Pajak perusahaan $20 \%$
$=$ Rp. $\quad 34.046 .735,60$
e. Keuntungan sesudah pajak $=$ Rp. $\quad 136.186 .942,40$

5. Perhitungan Pengembalian Modal

5.1. Persen keuntungan untuk mengembalikan modal

a. Sebelum pajak $=\frac{\text { Keuntungan sebelum pajak }}{\text { Total Modal }} \times 100 \%$ $=\frac{\text { Rp. } 170.233 .678,00}{\text { Rp. } 609.608 .534,00} \times 100 \%$

$=27,92$ s

b. Sesudah pajak

$=\frac{\text { Keuntungan sesudah pajak }}{\text { Total Modai }} \times$

$=\frac{\text { Rp. } 136 \cdot 186.942,40}{\text { Rp. } 609.608 .534,00} \times 100 \%$

$=22,34 \%$

5.2. Waktu pengembalian modal

a. Sebelum pajak

Total Modal

$=\frac{\text { Keuntungan sebelum pajak }+ \text { penyusutan }}{X} 1$ tahun

$=\frac{\text { Rp. } 609.608 .534,00}{\text { Rp. } 170.233 .678,00+\text { Rp. } 28.786 .340,00} \times 1$ tahun

$=3$ th 1 bulan

b. Sesudah pajak

Total Modal

$=\frac{\text { Keuntungan seudah pajak }+ \text { penyusutan }}{X} 1$ tahun

$=\frac{\text { Rp. } 609.608 .534,00}{\text { Rp. } 136 \cdot 186.942,40+\text { Rp. } 28.786 .340,00} \times 1$ tahun
$=3$ th 8 bulan

6. Perhitungan Batas Rugi Laba

6.1. Nilai batas rugi laba

$$
\begin{aligned}
& =\frac{\text { Biaya tetap }}{-1 \frac{\text { Biaya tidak tetap }}{\text { penjualan }}} \\
& =\frac{\text { Rp. } 204 \cdot 019 \cdot 583,00}{\text { Rp. } 1.105 .920 .000,00} \\
& =\text { Rp. } 620.120 .313,00
\end{aligned}
$$




$$
\begin{aligned}
& =\frac{\text { Rp. } 620.120 .313,00}{\text { Rp. } 1.105 .920 .000,00} \times 100 \% \\
& =56.07 \%
\end{aligned}
$$

6.3. Kapasitas batas rugi laba

$$
\begin{aligned}
& =56,07 \% \times 276.480 \mathrm{Kg} \\
& =155.022,336 \mathrm{Kg} \\
& =155 \mathrm{ton}
\end{aligned}
$$

\section{Kurva Batas Rugi Laba}

$$
\begin{array}{lll}
\text { Biaya tidak tetap } & =\mathrm{Rp} . & 742.034 .739,00 \\
\text { Biaya tetap } & =\mathrm{Rp} . & 204.019 .583,00 \\
\text { Total biaya produksi } & =\mathrm{Rp} . \quad 946.054 .322,00 \\
\text { Total penjualan } & =\mathrm{Rp} .1 .105 .920 .000,00 \\
\text { Persentase batas rugi laba } & =56,07 \%
\end{array}
$$

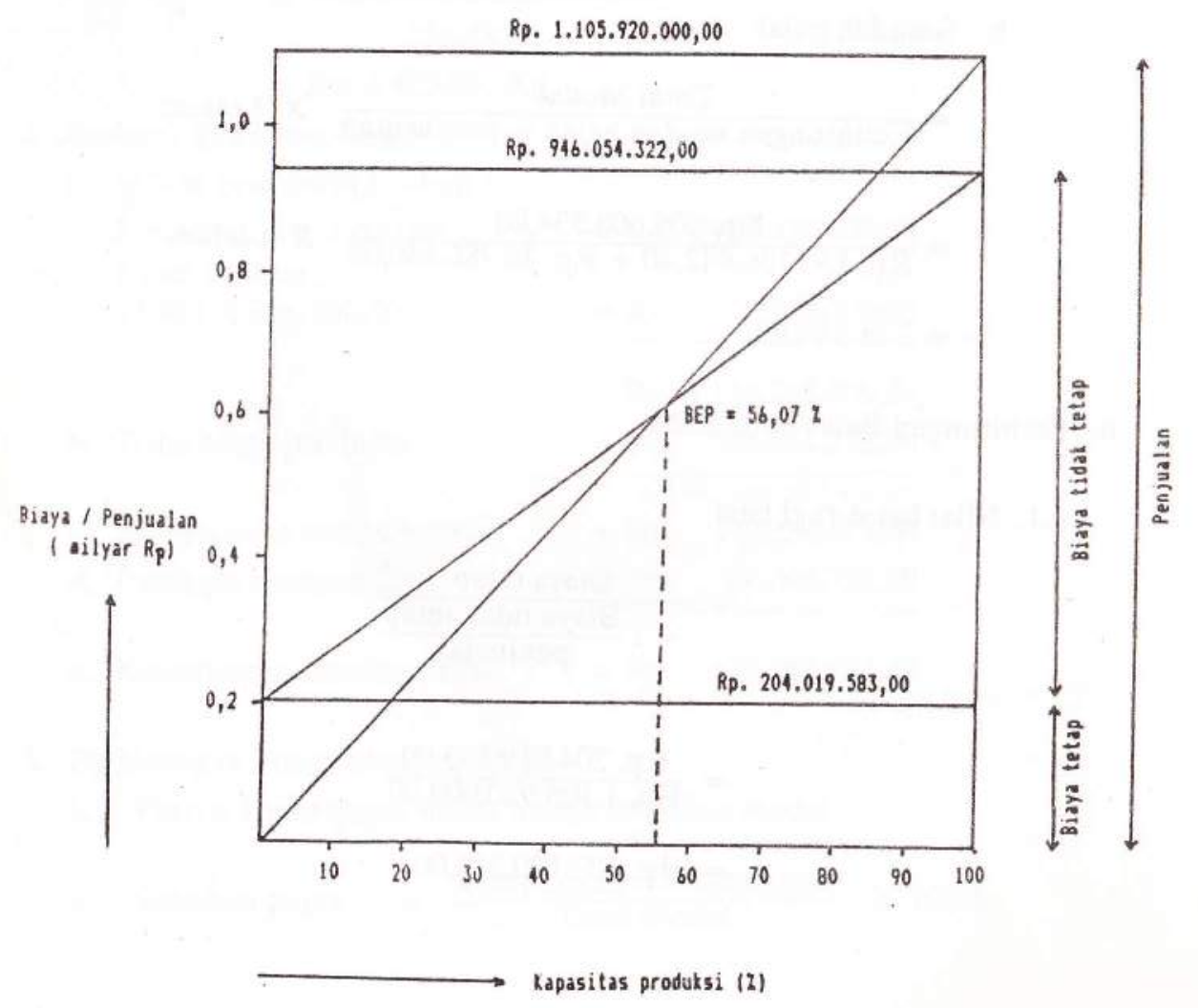

\section{KESIMPULAN}

Berdasarkan perhitungan analisa ekonomi dapat disimpulkan sebagai berikut :

- Dengan kapasitas produksi $960 \mathrm{Kg}$ per hari atau $276.480 \mathrm{Kg}$ per tahun, maka modal yang dibutuhkan sebesar Rp. 609.608.534,00 yang terdiri dari modal tetap Rp. 359.829.250,00 dan modal kerja Rp. 249.779.284,00

- Tenaga kerja yang dibutuhkan sebanyak 50 orang

- Biaya produksi 1 tahun sebesar Rp. 946.054.322,00, maka diperoleh harga pokok produksi Rp. $3.425,00$ per $\mathrm{Kg}$

- Apabila produk dijual dengan harga Rp. 4000,00 per $\mathrm{Kg}$, maka keuntungan sebelum pajak sebesar $27,92 \%$, keuntungan sesudah pajak $22,34 \%$, waktu pengembalian modal sebelum pajak 3 tahun 1 bulan dan sesudah pajak 3 tahun 8 bulan, sehingga diperleh prosentase batas rugi laba $56,07 \%$.

\section{DAFTAR PUSTAKA}

1. Perry's, Chemical Engineer's Handbook, third edition.

2. Peter and Thimmerhaus, Plant Design and Economics for Chemical Engineer, Mc Craw Hill, Kogakusha, 1978

3. Ruspandi dan B. Sumaryanto, Manfaat Penggunaan kantong Plastik Untuk pembibitan Tanaman, Proceeding Pertemuan Teknis Prospek Pemakaian Kantong Plastik Untuk Pembibitan Tanaman, BBKKP, Yogyakarta, 1991.

4. Siswanto Sutoyo, Studi Kelayakan Proyek Konsep dan Teknik, Pustaka Binaan Presindo, 1982.

\section{LAMPIRAN}

1. Bahan Baku

Kebutuhan bahan baku 1 hari :

Resin PE = $1.010 \mathrm{Kg} \times \mathrm{Rp} .2 .500,00 \quad=\mathrm{Rp} . \quad 2.525 .000,00$

Pewarna $=1 \mathrm{Kg} \times$ Rp. $15.000,00$

\section{Jumlah}

Kebutuhan bahan baku 3 bulan :

$$
=90 \times \text { Rp. } 2.540 .000,00
$$

Kebutuhan bahan baku 1 tahun :

$$
=288 \times \text { Rp. } 2.540 .000,00
$$

= Rp. $\quad 15.000,00$

= Rp. $\quad 2.540 .000,00$

$=$ Rp. $\quad 228.600 .000,00$

= Rp. $\quad 721 \cdot 520.000,00$

2. Utilitas

Kebutuhan listrik tiap hari $=540,4 \mathrm{Kwh}$

Tarip $1 \mathrm{Kwh}=\mathrm{Rp} 96,00$ dan biaya beban tiap bulan Rp. 3680,00

VOL VIII No. 15 Tahun 1992/1993 
Biaya listrik 1 th

$=(288 \times 540,4 \times$ Rp. 96,00$)+(12 \times R p 3680)$

= Rp. $14.985 .139,00$

3. Tanah dan bangunan

Luas tanah

$=1000 \mathrm{~m} 2 \times$ Rp. $20.000 / \mathrm{m} 2 \quad$ = Rp. $20.000 .000,00$ Luas bangunan

$$
\begin{aligned}
& =608 \mathrm{~m} 2 \times \text { Rp. } 200.000 / \mathrm{m} 2=\text { Rp. } 121.600 .000,00 \\
& \text { Jumlah } \\
& \text { =Rp. } \quad 141.600 .000,00
\end{aligned}
$$

4. Pengemasan

Dalam satu hari memproduksi kantong plastik $=960 \mathrm{Kg}$ Tiap $10 \mathrm{Kg}$ dikemas dalam 1 dos karton, harga 1 dos Rp.200,00

Kebutuhan pengemasan selama 3 bulan :

$$
=\frac{90 \times 960 \times 200}{10} \quad=\text { Rp. } 1.728 .000,00
$$

Kebutuhan pengemas selama 1 tahun :

$$
=\frac{288 \times 960 \times \text { Rp. } 200}{10}=\text { Rp. } 5.529 .600,0000
$$

\section{Peralatan}

Jumlah harga peralatan $=$ Rp. $92.380 .000,00$

\begin{tabular}{|c|c|c|c|c|}
\hline No. & Jenis Pekerjaan & $\begin{array}{l}\text { Jumlah } \\
\text { (orang) }\end{array}$ & $\begin{array}{c}\text { Gaji/orang/ } \\
\text { bl (Rp) }\end{array}$ & $\begin{array}{c}\text { Jmlgaji/bl } \\
\text { (Rp) }\end{array}$ \\
\hline 3. & Kabag Administrasi & 1 & $250.000,00$ & $250.000,0$ \\
\hline 4. & Kabag Pemasaran & 1 & $300.000,00$ & $300.000,0$ \\
\hline 5. & Kabag Gudang & 1 & $100.000,00$ & $100.000,0$ \\
\hline 6. & Staf Administrasi & 2 & $125.000,00$ & $250.000,0$ \\
\hline 7. & Staf Pemasaran & 2 & $150.000,00$ & $300.000,0$ \\
\hline 8. & Keamanan & 6 & $50.000,00$ & $300.000, \mathrm{C}$ \\
\hline 9. & Kebersihan & 3 & $40.000,00$ & $120.000, \mathrm{C}$ \\
\hline 10. & Sopir & 1 & $65.000,00$ & $65.000, \mathrm{C}$ \\
\hline \multicolumn{2}{|r|}{ Jumlah } & 50 & & 5.235 .000 \\
\hline
\end{tabular}

6. Jumlah dan gaji karyawan

\begin{tabular}{|c|l|c|r|r|}
\hline No. & \multicolumn{1}{|c|}{ Jenis Pekerjaan } & $\begin{array}{c}\text { Jumlah } \\
\text { (orang) }\end{array}$ & $\begin{array}{c}\text { Gaji/orang/ } \\
\text { bl (Rp) }\end{array}$ & \multicolumn{1}{c|}{$\begin{array}{c}\text { Jmigaji/bl } \\
\text { (Rp) }\end{array}$} \\
\hline I & Tenaga kerja langsung & & & \\
1. & Operator mesin ekstrusi & 6 & $100.000,00$ & $600.000,00$ \\
2. & Operator mesin las otomatis & 4 & $60.000,00$ & $240.000,00$ \\
3. & Melubangi kantong plastik & 3 & $50.000,00$ & $150.000,00$ \\
4. & Teknisi Mesin & 3 & $75.000,00$ & $225.000,00$ \\
5. & Pengawas & 3 & $150.000,00$ & $450.000,00$ \\
6. & Gudang & 8 & $75.000,00$ & $600.000,00$ \\
7. & Pengemasan & 4 & $50.000,00$ & $200.000,00$ \\
II & Tenaga Kerja Tak Langsung & & & \\
1. & Pimpinan & 1 & $700.000,00$ & $700.000,00$ \\
2. & Kabag Produksi & 1 & $400.000,00$ & $400.000,00$ \\
\hline
\end{tabular}

Gaji 3 bulan $=3 \times$ Rp. $5.235 .000,00=$ Rp. $15.705 .000,00$ Gaji 1 bulan $=12 \times$ Rp. $5.325 .000,00=$ Rp. $62.820 .000,00$ 